Jpn. J. Oral Biol., $38:$ 345-353, 1996.

\title{
ORIGINAL
}

\section{In vitro measurement of three-dimensional tooth movement following insertion and removal of an elastic band between rat molars using a time-lapse video and radiography}

\author{
Akira Yamane, Tadayoshi Fukui* and Mototsugu Chiba \\ Department of Pharmacology, School of Dental Medicine, Tsurumi University \\ *Department of Orthodontics, School of Dental Medicine, Tsurumi University \\ 2-1-3 Tsurumi, Tsurumi-ku, Yokohama, Japan 230 \\ (Received on February 16, 1996 ; Accepted on June 4, 1996)
}

Key words : in vitro/tooth movement/rat molars/time-lapse video/radiography

\begin{abstract}
Three-dimensional tooth movements in vitro were examined for 20 hours following insertion of an elastic band between the rat mandibular first and second molars and then for 10 hours following removal of the band using a time-lapse video in combination with radiography. The first molar moved in a mesiolingual direction and the second molar, in a distobuccal direction following insertion of the band. The most pronounced expansion in the interdental space occurred during the first hour following the insertion of the band. Following the removal of the band, the expanded interdental space began to close immediately, however, the teeth had not returned to their initial positions by the end of the experimental period. Two distinct peaks were observed in the rates of tooth movement, one immediately following the insertion of the band and the other following its removal. Radiographic observations showed that the first molar exhibited a mesial tipping movement while the second molar exhibited not only a distal tipping movement but also an upward movement following the insertion of the band : relapsing movements were also observed following the removal of the band. These results suggest that the present in vitro tooth movements were mainly caused by the biomechanical responses of the periodontal ligament to orthodontic forces, and that our method is relatively simple, compared to in vivo experiments, and may be a useful tool for further studies on threedimensional tooth movements under various experimental conditions.
\end{abstract}

抄録：摘出したラット下顎第一および第二臼歯間にゴムバンドを挿入し 20 時間にわたり，またバンド除去後 10 時間にわたり, 臼歯の三次元的な運動をコマ撮りビデオと軟X線写真撮影法を用いて解析した。バンド挿入後, 第一臼歯は近心一舌側方向へ移動し，第二曰歯は遠心一頖側方向へ移動した。バンド挿入後 1 時間内に歯間離開 距離の最も大きな増大が観察された。バンド除去後, この距離は急激に減少したが, 実駼終了時においても, 完 全にはもとに戻らなかった。軟X線写真撮影法を用いた観察より, バンド挿入後第一臼歯は近心方向へ傾斜運動 すること, また, 第二臼㐘は遠心方向への傾斜運動に加えて, 上昇運動することが示された。これらの結果から, このような歯の動きは，主として，外力に対する歯根膜の機械的反応による可能性が示唆された。本方法は比較 的簡単であり，様々な実験条件下における臼歯の三次元的な運動を解析するために有用と考えられる。

\section{Introduction}

Tooth movements and accompanying tissue reactions have generally been investigated using an experi- mental model in which an elastic band is inserted between the molars in rats ${ }^{1-3)}$. It has been demonstrated that movements of rat molars following the insertion of an elastic band are complex, and include horizontal, rotating, tipping, and upward motions ${ }^{1,4,5}$. 
The relapse of moved teeth after orthodontic treatment is a of primary concern of orthodontists ${ }^{6}$. However, it seems that relapsing tooth movements and the reaction of supporting tissues following removal of orthodontic appliances have not been fully investigated $^{7 \sim 9)}$

A number of different methods have been used to investigate one- or two-dimensional tooth movements in experimental animals ${ }^{10 \sim 12)}$ and in humans ${ }^{13 \sim 16)}$. To analyze three-dimensional tooth movement, elaborate apparatus and theoretical assumptions have been employed $^{17 \sim 19}$.

Recently, we developed a simple technique to measure the movements of rat molars in vitro, using a time-lapse video recorder ${ }^{20}$. Our technique allows easy visualization and analysis of two-dimensional tooth movements stored on videotapes. We assumed that it would be easier to analyze three-dimensional tooth movements using a time-lapse video in combination with radiography.

The purpose of the present study was to analyze three-dimensional tooth movements in vitro following insertion and removal of an elastic band between the rat mandibular first and second molars.

\section{Materials and Methods}

\section{Experimental animals}

Thirty-three male Wistar rats, 8 to 9 weeks old, with a mean body weight of $253 \pm 13$ (SD) g (hereinafter the term, SD, will be omitted) were used in this experiment. They were anesthetized with ether and killed by decapitation. Immediately after death, the right mandibles were dissected, adhering soft tissues removed, and two experiments were performed as follows.

\section{Experiment 1. Measurement of tooth move- ment using a time-lapse video recorder}

Three groups of seven to eight rats were used. Following insertion of an elastic band (No. 404-126, Unitek, Monrovia, CA, U. S. A., average thickness, $670 \pm 33 \mu \mathrm{m}$ ) between the first and second molars in the dissected mandible, in vitro movements of the teeth were recorded at 1-hour intervals over a period of 5,10 or 20 hours $\left(5^{-}, 10^{-}\right.$, or 20 -hour group, respectively) using a time-lapse video recorder (SIV-JS, Sankei, Tokyo, Japan) as described in our previous work ${ }^{20}$. Following the removal of the band, the relapsing movements of the teeth were also measured at 1hour intervals over a period of 10 hours in all groups. The mandibles were immobilized and kept in phosphate-buffered saline containing antibiotics (50 units of penicillin $G$ and $50 \mu \mathrm{g}$ of streptomycin $/ \mathrm{m} l$; GIBCO, New York, U.S. A.) at room temperature, approximately 20 to $25^{\circ} \mathrm{C}$, during the experimental period.

The immobilization of the mandible, labeling of reference points, and data analyses were also performed as previously described ${ }^{20}$. In brief, the dissected mandible was secured by a hemostatic clamp and self -curing resin; reference points were chosen on the surfaces of the first and second molars and marked with oily marking ink ; an image of the two reference points was taken through a stereomicroscope, using a television camera connected to the time-lapse video recorder ; and the data processed with an image analyzer. Data analyses included representing the movements of the reference points as traced lines of the reference points, and calculating the rates of tooth movements and the interproximal distance between the first and second molars along the midline of the dental arch (interdental space).

\section{Experiment 2. Measurement of tooth move- ment using a radiographic method}

A group of 11 rats was used. Following the insertion of an elastic band between the first and second molars in the dissected mandible, lateral radiographs were taken from the lingual side using a soft- $x$-ray apparatus (Type EMB, Softex, Tokyo, Japan), at 0 (just before insertion of the band), 5, 10 and 20 hours. Following the removal of the band, radiographs were taken at 5 and 10 hours. The mandibles were kept in phosphate-buffered saline containing antibiotics at room temperature, approximately 24 to $26^{\circ} \mathrm{C}$, during the experimental period.

To examine tipping and vertical tooth movements, radiographs were placed on a transparent glass plate and the radiographic images taken with the television 
camera and sent to the image analyzer. Distances between the reference points were measured on the screen of the image analyzer at a magnification of $x$ 117. The resolution was estimated to be $3.6 \mu \mathrm{m}$. As shown in Figure 1, the distances between the tips of

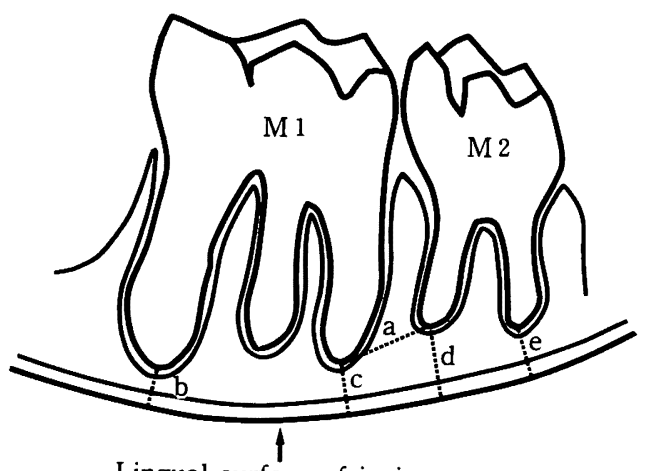

Lingual surface of incisor

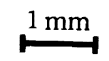

Fig. 1 Diagrammatic representation of a radiograph of the mandibular first (M1) and second (M2) molars. The lengths shown by dotted lines a, b, c, d, and $e$ were measured following insertion of an elastic band between the teeth over a 20-hour period, and following removal of the band over a 10-hour period. the distal root of the first molar and the mesial root of the second molar (a) ; between the incisor surface and the tip of the mesial root (b) or the distal root (c) in the first molar; and between the incisor surface and the tip of the mesial root (d) or the distal root (e) in the second molar.

\section{Statistical Analyses}

Student's $t$-test was used to compare the mean values between the relevant two groups. After analysis of variance (ANOVA) was used for multiple comparisons, Scheffe's method ${ }^{21)}$ was used to compare the mean values between the appropriate two points or groups.

\section{Results}

\section{Tooth movements measured by time-lapse video recorder}

Movements of reference points

Figure 2 shows traced lines representing the movements of reference points relative to a parallel line of the midline of the dental arch over a 20 -hour period

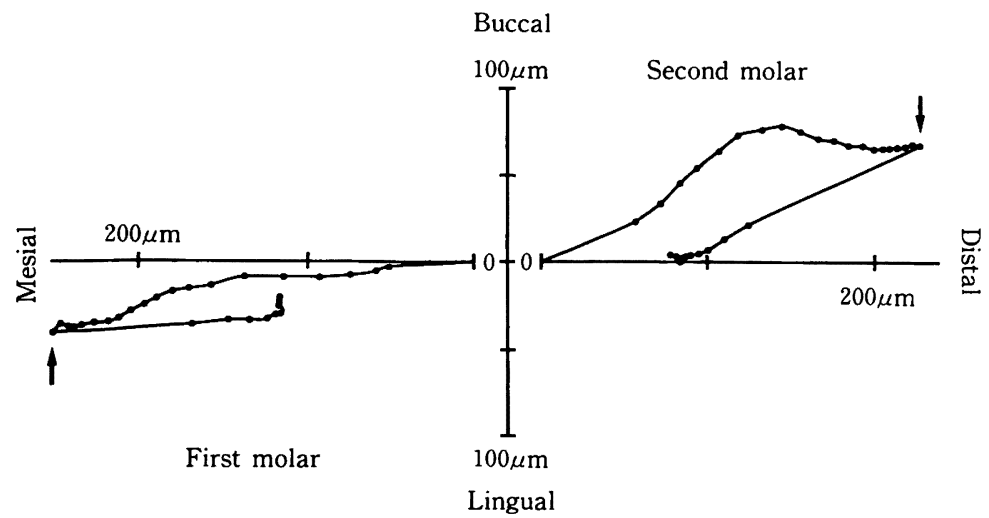

Fig. 2 Movements of the reference points on the tooth surfaces of the first and second molars, depicted as traced lines, following the insertion of an elastic band between the teeth over a 20-hour period, and following the removal of the band over a 10-hour period. Each dot represents the position of the reference point measured at 1 -hour intervals. The horizontal axis is parallel to the midline of the dental arch. The positions of the reference points before band insertion are labeled as 0 . Arrows indicate the positions of the reference points when the band was removed. Mean values collected from eight animals are shown. 


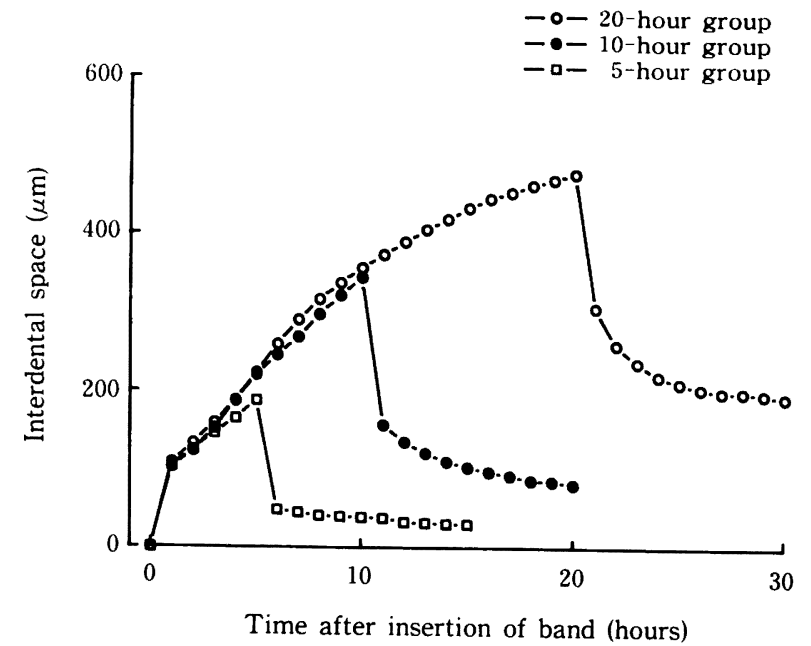

Fig. 3 Changes in the interdental space between the first and second molars following the insertion of an elastic band between the teeth over 5,10 , or 20 hour period, and following the removal of the band over 10-hour period, measured at 1-hour intervals. Each point represents the mean of data collected from seven or eight animals.

following the insertion of an elastic band between the teeth, and for the successive 10 hours following the removal of the band in the 20-hour group measured at 1-hour intervals.

The reference point on the first molar moved in a mesiolingual direction and that on the second molar moved in a distobuccal direction following the insertion of the band. The movements were greater in the first hour. The total amount of mesial movement in the first molar $(249 \pm 32 \mu \mathrm{m})$ was similar to that of the distal movement in the second molar $(227 \pm 52$ $\mu \mathrm{m})$; the difference was not significant ( $t$-test). However the total amount of lingual movement in the first molar $(41 \pm 43 \mu \mathrm{m})$ appeared to be less than that of the buccal movement in the second molar $(66 \pm 69$ $\mu \mathrm{m})$ although the difference was not significant $(t-$ test). The traced lines in both the first and second molars were irregular.

Following the removal of the band over a period of 10 hours, relapsing movements were observed in both the first and second molars. The movements were also greater in the first hour. The reference points on both the first and second molars did not return to their initial positions by the end of the experimental period.
The traced lines were regarded as straight initially but became irregular toward the end of the experimental period.

Interdental space

Figure 3 shows changes in the interdental space between the first and second molars following the insertion of the band between the teeth and following the removal of the band over 10 hours in the 5-, 10-, and 20 -hour groups measured at 1 -hour intervals. The most pronounced expansion in the interdental space occurred during the first hour following the insertion of the band. The interdental space increased at slower rates afterward. The greatest mean interdental spaces were $188 \pm 39 \mu \mathrm{m}, 344 \pm 122 \mu \mathrm{m}$ and $476 \pm 67 \mu \mathrm{m}$ in the $5^{-}, 10^{-}$and 20 -hour groups respectively; the differences between any two groups were all significant ( $p<0.05-p<0.001$, Scheffe's method). Following the removal of the band, the expanded interdental space began to close immediately. Relapsing movements were most pronounced in the first hour and were slower thereafter in all groups. However, the teeth had not returned to their initial positions by the end of the experimental period. The mean remaining spaces were $30 \pm 29 \mu \mathrm{m}, 81 \pm 32 \mu \mathrm{m}$ and $192 \pm 52 \mu \mathrm{m}$ in the $5-$, 10 - and 20-hour groups respectively; the difference between the 5 - and 10-hour groups was not significant (Scheffe's method) but the differences between 5- and 20 -hour groups, and 10-and 20-hour groups were significant $(\mathrm{p}<0.001$, Scheffe's method).

\section{Rates of tooth movement}

Figure 4 shows the changes in the rates of movement of the first and second molars over a 20-hour period following the insertion of an elastic band between the teeth, and over a 10-hour period follow. ing the removal of the band, measured at 1-hour intervals. Two distinct peaks were observed, one immediately following the insertion of the band and the other following its removal. The rates in the first hour following the insertion of the band were $59 \pm 11$ $\mu \mathrm{m} /$ hour in the first molar and $62 \pm 22 \mu \mathrm{m} /$ hour in the second molar, and those after the removal of the band were $81 \pm 18 \mu \mathrm{m} /$ hour in the first molar and $90 \pm 38$ $\mu \mathrm{m} /$ hour in the second molar ; the values being significantly greater than those recorded at all later times $(\mathrm{p}<0.05-0.001$, Scheffe's method). The mean rates in 


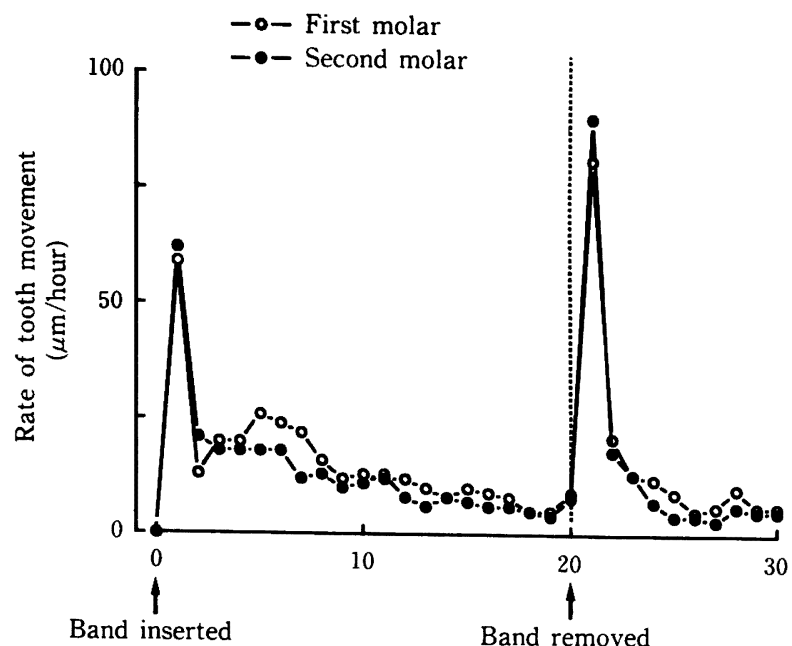

Time (hours)

Fig. 4 Rates of tooth movement ( $\mu \mathrm{m} /$ hour) in the first and second molars following the insertion of an elastic band between the teeth over a 20-hour period, and following the removal of the band over a 10-hour period. Each point represents the mean of data collected from seven or eight animals.

the first hour following the removal of the band were greater than those occurring after the insertion of the band, in both the first and second molars, although the difference was not significant (Scheffe's method). The rates were $6 \pm 3 \mu \mathrm{m} /$ hour in the first molar and $5 \pm 4 \mu \mathrm{m} /$ hour in the second molar at the end of the experimental period.

\section{Tooth movements measured by using the radiographic method}

Figure 5 shows changes in the distance between the tips of the distal root of the first molar and the mesial root of the second molar (see Figure 1, dotted line a) following the insertion of an elastic band between the teeth over a 20-hour period, and following the removal of the band over a 10 -hour period. The initial distance was $1.43 \pm 0.05 \mathrm{~mm}$. Following the insertion of the band, the mean distance between the root tips decreased gradually and reached to $1.19 \pm 0.10 \mathrm{~mm}$ at 20 hours which was significantly less than the initial value $(p<0.001$, Scheffe's method). Following the removal of the band, relapsing movements of the root tips were observed. The mean distance reached to $1.33 \pm 0.08 \mathrm{~mm}$ at the end of the experimental period ;

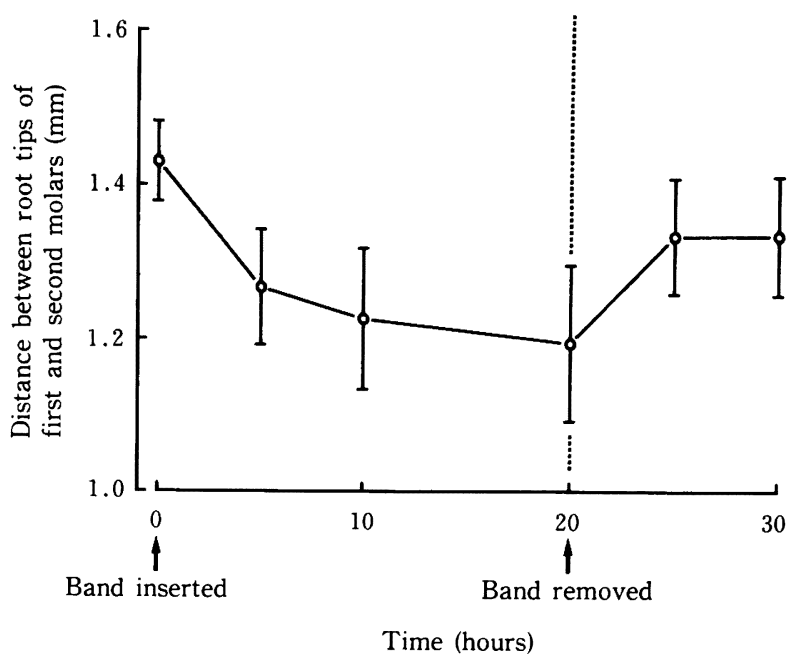

Fig. 5 The distance between the tips of the distal root of the first molar and the mesial root of the second molar following the insertion of an elastic band between the teeth over a 20 -hour period, and following the removal of the band over a 10-hour period (see Figure 1, dotted line a). Each point and vertical bar represents the mean $\pm 1 \mathrm{SD}$ of data collected from seven or eight animals.

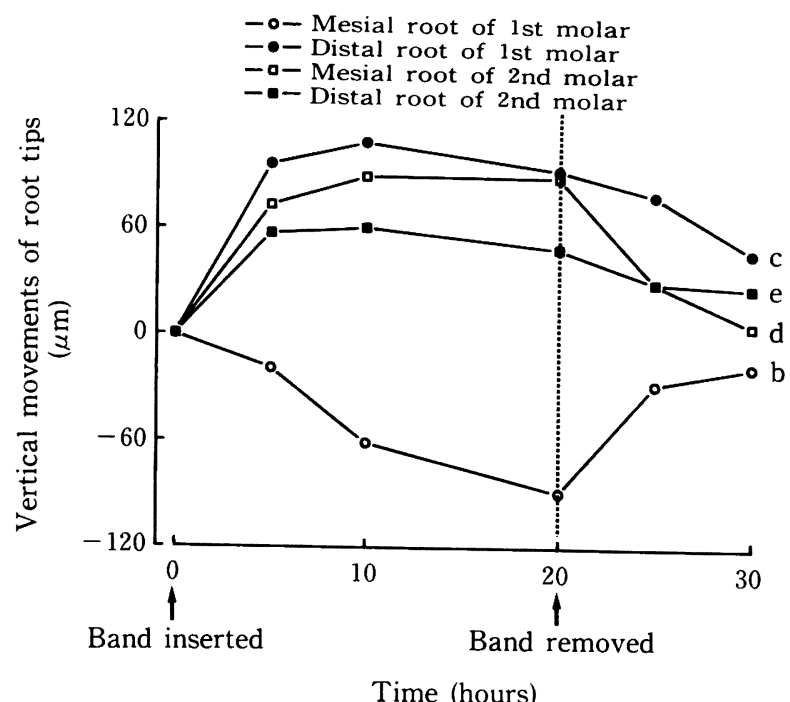

Fig. 6 The vertical movements of tips of the mesial and distal roots of the first and second molars measured from the incisor surface following the insertion of an elastic band between the teeth over a 20 hour period, and following the removal of the band over a 10-hour period (see Figure 1, dotted lines b, $\mathrm{c}, \mathrm{d}$, and e). Each point represents the mean of data collected from seven or eight animals. 
this value being significantly greater than the value at 20 hours ( $p<0.01$, Scheffe's method) and was less than the initial value $(p<0.01$, Scheffe's method). Thus the approach of the proximal root tips of the first and second molars following the insertion of the band, and the separation of the root tips following its removal were observed in contrast with the changes in the interdental space measured on the tooth surfaces (Fig. $3)$.

Figure 6 shows changes in the distances between the incisor surface and root tips in the mesial and distal roots of the first and second molars (see Figure 1, dotted lines b, c, d, and e) following the insertion of an elastic band between the teeth over a 20 -hour period, and following the removal of the band over a 10-hour period. In the first molar, the tip of the distal root moved upward (c, $92 \pm 53 \mu \mathrm{m} / 20$ hours) but the tip of the mesial root moved downward (b, $-89 \pm 56 \mu \mathrm{m} / 20$ hours) following the insertion of the band. In the second molar, the tips of both the mesial and distal roots moved upward following the insertion of the band, but the amount of upward movement was greater in the mesial $(\mathrm{d}, 88 \pm 61 \mu \mathrm{m})$ than in the distal (e, $48 \pm 38 \mu \mathrm{m}$ ) roots at 20 hours ; the difference was not significant ( $t$-test). Relapsing movements of the root tips in both the first and second molars were observed following the removal of the band, but the root tips had not returned to their initial positions by the end of the experimental period ; the mean values being $-18 \pm 29 \mu \mathrm{m}$ (b) and $46 \pm 61 \mu \mathrm{m}$ (c) in the mesial and distal roots of the first molar respectively, and $5 \pm 61 \mu \mathrm{m}$ (d) and $26 \pm 36 \mu \mathrm{m}$ (e) in the mesial and distal roots of the second molar respectively at the end of the experimental period.

\section{Discussion}

In our previous study concerning the in vitro measurement of orthodontic tooth movement, using a timelapse video recorder, we were able to detect the effects of $\beta$-aminopropionitrile and hydrocortisone given to living animals on the periodontal ligament and alveolar bone ${ }^{20}$. Therefore, we assume that the results obtained in the present experiment could represent three-dimensional movements of teeth as the result of mechanical responses of the periodontal ligament and alveolar bone following application and removal of an orthodontic force as in in vivo experiments. It has been suggested that, in addition to biomechanical responses of the periodontal ligament and alveolar bone, many factors such as changes in vasculature $^{22,23)}$, bone resorption and apposition ${ }^{2,4)}$, remodeling of periodontal ligament ${ }^{24,25)}$, abnormal muscle function ${ }^{6,8}$, occlusal stress ${ }^{6)}$ and supra-alveolar structures ${ }^{7,26)}$ can contribute to orthodontic tooth movements in vivo. It was not possible to examine the effects of such factors on experimental tooth movements in the present in vitro study.

In vitro tooth movement was observed for a total of 30 hours in the present experiment. Chiba $e t a l^{27}$. have reported that the storage of jaws in cold saline for a period of up to 32 hours did not cause any significant changes in the ultimate loads required to extract the rat mandibular first molar; and they suggested that the effects of postmortem changes on the mechanical properties of the periodontal ligament were minor under those experimental conditions. In addition, Viidik et $a l^{28}$. have shown that the tensile characteristics of rabbit ligaments were not influenced by storage at temperatures of 18 to $20^{\circ} \mathrm{C}$ for a period as long as 96 hours. Although some degradation of the periodontal ligament could have occurred during our experiments, the effects of such tissue degradation on experimental tooth movements in vitro would have been minor.

Tsuruta $e t a l^{299}$. have reported that, in living animals, the interdental space between the rat mandibular first and second molars did not return to the initial size until the fourth day after an orthodontic force was removed. In the present in vitro experiment, we found that the interdental space did not return to its initial size during a 10-hour period. In addition, the longer the time when the band was kept between the teeth, the wider the remaining space (Fig. 3). It is possible that the application of an orthodontic force causes breakage of the periodontal ligament, and that the degree of tissue damage becomes greater when the force is applied for a longer period in both in vivo and in vitro experimental conditions. In our in vitro experiment, the damaged tissues cannot be repaired 
biologically; therefore, the present results may reflect the extent of tissue damage related to the length of time when the band remained between the teeth.

The traced lines representing tooth movement were irregular following the insertion of the band, but regarded as straight following the removal of the band except at the end of the 10-hour experimental period (Fig. 2). Ohkawa ${ }^{30}$ ) has suggested that the magnitude of the applied force may change after the band is inserted between the teeth, possibly due to an initial intense compression of the rubber band and the gradual release of the compression as the teeth separate, coupled with the deformation of soft tissues. Changes in the magnitude of the applied force and the complex structures of teeth, with a varying number of roots, surrounded by the periodontal ligament may result in multi-directional tooth movement. The straight lines depicting tooth movement just after band removal may represent a uni-directional relapsing movement of the teeth caused by the sudden release of a large stress that had been acting on the dental tissues. The irregular lines seen during the latter portion of the experimental period may reflect complex relapsing movements of the teeth caused by weak retractive forces following the release of a large stress on the dental tissues. It was not possible to determine the distribution of the differential forces acting on the various parts of the alveolar bones, teeth, and periodontal ligament, which may contribute to the complex shapes of the traced lines (irregular tooth movements) observed in the present study.

Two peaks in the rates of tooth movement were observed in the present experiment, one following band insertion, and the other following its removal (Fig. 4). The peak following band insertion seems to reflect a rapid increase and subsequent decrease in the force exerted on the tooth soon after the band was inserted ${ }^{30}$. While the band remained between the teeth, the periodontal ligament, roots, and alveolar bones were probably under stress and were deformed. It is possible that the peak occurring immediately after band removal reflects a rapid and marked restoration of these large deformations. The magnitude of the force exerted on the teeth just prior to band removal was probably much lower than that immediately following its insertion, as suggested by Ohkawa $^{30)}$.

Previous studies have shown that the movements of rat molars following the insertion of an elastic band between the teeth include horizontal, rotating, tipping, and upward movements ${ }^{1,4,5,22)}$. In the present study, we observed that, following band insertion, the first molar exhibited only the tipping movement toward the mesial direction while the second molar exhibited distal tipping and upward movements. It appears that the second molar did not have enough space to move distally because of the proximity of the third molar, thus exhibiting tipping and upward movements. It has previously been suggested that orthodontic tooth movement is affected by a number of factors such as the magnitude and duration of the applied force $\mathrm{e}^{31 \sim 33)}$, the number and shape of roots ${ }^{4}$, and the mechanical characteristics of the periodontal ligament ${ }^{20}$. In addition, it is likely that the proximity of adjacent teeth plays a role in orthodontic tooth movement.

Reitan $^{26)}$ has shown that most of the relapsing movement occurred in the upper lateral incisor of a 12-year-old patient during the first day following the removal of an orthodontic appliance. In the present study, we observed that the straight, rapid, and large relapsing movements occurred shortly after band removal. These results suggest that in order to obtain successful results from orthodontic treatments, it is important to prevent these rapid and large relapsing movements by inserting retention appliances immediately after removal of orthodontic appliances ${ }^{3,8,34}$.

In conclusion, we were able to obtain a three-dimensional measurement of in vitro tooth movements following the insertion and removal of an elastic band between the rat mandibular first and second molars, by combining time-lapse video and radiography. The present results appear to represent mainly biomechanical responses of the periodontal ligament shortly after application and removal of orthodontic force in teeth of experimental animals, but they do not reflect biological responses such as changes in vasculature, bone resorption and apposition, remodeling of the ligament etc. However our method is relatively simple compared to in vivo experiments and may be a useful 
tool for further studies on three-dimensional tooth movement under various experimental conditions.

\section{References}

1) Waldo, C. M. and Rothblatt, J. M. : Histologic response to tooth movement in the laboratory rat. Procedure and preliminary observations. J. Dent. Res. 33 : 481 486, 1954.

2) Tanaka, T., Morioka, T., Ayasaka, N., Ijima, T. and Kondo, T. : Endocytosis in odontoclasts and osteoclasts using microperoxidase as a tracer. J. Dent. Res. 69 : 883 889, 1990.

3) Hong, R. K., Yamane, A., Kuwahara, Y. and Chiba, M. : The effect of orthodontic retention on the mechanical properties of the periodontal ligament in the rat maxillary first molar. J. Dent. Res. 71: 1350 1354, 1992.

4) Macapanpan, L. C., Weinmann, J. P. and Brodie, A. G. : Early tissue changes following tooth movement in rats. Angle Orthod. $24: 79 \sim 95,1954$.

5) Baumrind, S : A reconsideration of the propriety of the "pressure-tension" hypothesis. Am. J. Orthod. $55:$ 12 22, 1969.

6) Reitan, K. : Principles of retention and avoidance of posttreatment relapse. Am. J. Orthod. 55 : 776 $\sim 790,1969$.

7) Reitan, K. : Tissue rearrangement during retention of orthodontically rotated teeth. Angle Orthod. $29: 105 \sim 113,1959$.

8) Reitan, K. and Rygh, P. : Relapse and retention. In: Orthodontics. Current principles and techniques (edited by Graber, T. M. and Vanarsdall, R. L. Jr.), pp. 181 187, Mosby-Year Book, St. Louis, 1994.

9) Horowitz, S. L. and Hixon, E. H. : Physiologic recovery following orthodontic treatment. Am. J. Orthod. $55: 1 \sim 4,1969$.

10) Moxham, B. J. : Recording the eruption of the rabbit mandibular incisor using a device for continuously monitoring tooth movements. Archs. Oral Biol. $24:$ 889 899, 1980.

11) Aars, H.: The influence of sympathetic nerve activity on axial position of the rabbit incisor tooth. Acta Physiol. Scand. 116 : 417 421, 1982.

12) King, G. J., Keeling, S. D., McCoy, E. A. and Ward, T. H. : Measuring dental drift and orthodontic tooth movement in response to various initial forces in adult rats. Am. J. Orthod.
Dentofac. Orthop. $99: 456 \sim 465,1991$.

13) Trentini, C. J., Brown, W. H., Paterson, R. L. and Proffit, W. R. : The application of moire magnification to high-resolution studies of human premolar eruption. Archs. Oral Biol. 40:623 $\sim 629,1995$.

14) Lee, C. F. and Proffit, W. R. : The daily rhythm of tooth eruption. Am. J. Orthod. Dentofac. Orthop. $107: 38 \sim 47,1995$.

15) Parfitt, G. J. : Measurement of the physiological mobility of individual teeth in an axial direction. J. Dent. Res. $39: 608 \sim 618,1960$.

16) Proffit, W. R., Prewitt, J. R., Baik, H.S. and Lee, C. F. : Video microscope observations of human premolar eruption. J. Dent. Res. 70 : 15 18, 1991.

17) Burstone, C. J., Every, T. W. and Pryputniewicz, R. J. : Holographic measurement of incisor extrusion. Am. J. Orthod. $82:$ 1 9, 1982.

18) Tanne, K., Koenig, H. A. and Burstone, C. J. : Moment to force ratios and the center of rotation. Am. J. Orthod. Dentofac. Orthop. 94: 426 431, 1988.

19) Pedersen, E., Andersen, K. and Melsen, B. : Tooth displacement analysed on human autopsy material by means of a strain gauge technique. Eur. J. Orthod. $13: 65 \sim 74,1991$.

20) Yamane, A., Fukui, T. and Chiba, M.: In vitro measurement of orthodontic tooth movement in rats given $\beta$-aminopropionitrile or hydrocortisone using a time lapse videotape recorder. Eur. J. Orthod. (in press).

21) Sokal, R. R. and Rohlf, F. J. : Biometry. The principles and practice of statistics in biological research. 2nd ed., pp. 208 270, W. H. Freeman and Company, New York, 1981.

22) Zaki, A. E. and Van Huysen, G. : Histology of the periodontium following tooth movement. J. Dent. Res. $42:$ 1373 1379, 1963.

23) Kuitert, R. B., Van de Velde, J. P., Hoeksma, J. B. and Prahl-Andersen, B.: Tissue changes in the rabbit periodontal ligament during orthodontic tooth movement. Acta Morphol. Neerl. -Scand. $26: 191 \sim 206,1988 / 89$.

24) Azuma, M. : Study on histologic changes of periodontal membrane incident to experimental tooth movement. Bull. Tokyo Med. Dent. Univ. $17: 149 \sim 178,1970$.

25) Diaz, E. A. : Periodontal ligament collagen response to tooth movement: Histochemical and 
autoradiographic reactions. Am. J. Orthod. 73 : 443 458, 1978.

26) Reitan, K. : Clinical and histologic observations on tooth movement during and after orthodontic treatment. Am. J. Orthod. $53: 721 \sim 745,1967$.

27) Chiba, M., Kinoshita, Y., Nakamura, G., Ohshima, S., Ishikawa, S., Tsuruta, M. and Ozawa, M. : Effects of storage of jaws in saline and of velocity of loading on the force required to extract the rat mandibular first molar. Archs. Oral Biol. 27 : 905 〜907, 1982.

28) Viidik, A., Sandqvist, L. and Mägi, M. : Influence of postmortal storage on tensile strength characteristics and histology of rabbit ligaments. Acta Orthop. Scand. 79 (Suppl.) : 7〜38, 1965.

29) Tsuruta, M., Ohkawa, S., Nakatani, Y., Kuwahara, Y. and Chiba, M. : Effect of experimental tooth movement on the mechanical strength of the periodontium in the rat mandibular first molar.
Archs. Oral Biol. 27 : 875 879, 1982.

30) Ohkawa, S. : Effects of orthodontic forces and anti-inflammatory drugs on the mechanical strength of the periodontium in the rat mandibular first molar. Am. J. Orthod. $81: 498 \sim 502$, 1982.

31) Reitan, K. : Tissue behavior during orthodontic tooth movement. Am. J. Orthod. 46:881 900, 1960.

32) Reitan, K. : Effects of force magnitude and direction of tooth movement on different alveolar bone types. Angle Orthod. $34: 244 \sim 255,1964$.

33) Reitan, K. : Biomechanical principles and reactions. In : Current orthodontic concepts and techniques. (edited by Graber, T. M. and Swain, B. F.), pp. 111 229, W. B. Saunders Company, Philadelphia, 1975.

34) Proffit, W. R. : Contemporary orthodontics. pp. 534 551, Mosby-Year Book, St. Louis, 1993. 